\title{
INFLUENCE OF VINASSE APPLICATION IN HYDRAULIC CONDUCTIVITY OF THREE SOILS
}

\section{CLAUDIO A. UYEDA ${ }^{1}$, JARBAS H. DE MIRANDA ${ }^{2}$, SERGIO N. DUARTE ${ }^{3}$, PEDRO R. F. DE MEDEIROS ${ }^{4}$, CARLOS T. DOS S. DIAS ${ }^{5}$}

\begin{abstract}
The potassium ion, present in great amount in the vinasse because it is a monovalent cation, has the characteristic of promoting the dispersion of clay particles, in the same way as the sodium, causing a reduction in the pore space of the soil and, in its turn, reducing its permeability. To evaluate this effect of reduction by application of vinasse to the soil, an experiment was conducted for three different soils, with the objective of evaluating the effect of the application of different doses of vinasse on hydraulic conductivity of saturated soil and verifying its possible chemical changes of these soils. For that, it was used PVC columns (in a scheme of constant head permeameter to obtain the values of hydraulic conductivity of saturated soil), filled with three soils - Dark Red Latosol (DRL), Purple Latosol (PL) and Eutrophic Red Nitossol (ERN) -, in which were applied four doses of vinasse $\left(0,150,300\right.$ and $\left.450 \mathrm{~m}^{3} \mathrm{ha}^{-1}\right)$, distributed in a completely randomized design with a 3x4 factorial scheme with three replications. The results evidenced that only the Dark Red Latosol (DRL) showed a reduction in the values of hydraulic conductivity of saturated soil, and in front of the application of vinasse, up to $300 \mathrm{~m}^{3} \mathrm{ha}^{-1}$, it was observed an increase in the concentrations of potassium, calcium and cation exchange capacity (CEC) ions.
\end{abstract}

KEYWORDS: Clay dispersion, Potassium, Soil permeability.

\section{INFLUÊNCIA DA APLICAÇÃO DE VINHAÇA NA CONDUTIVIDADE HIDRÁULICA DE TRÊS SOLOS}

RESUMO: O íon potássio, presente em grande quantidade na vinhaça, por se tratar de um cátion monovalente, tem a característica de promover a dispersão das partículas de argila, assim como o sódio, provocando redução do espaço poroso do solo e, por sua vez, reduzindo sua permeabilidade. Para avaliar este efeito de redução mediante a aplicação de vinhaça ao solo, realizou-se um experimento para três diferentes solos, com o objetivo de avaliar o efeito da aplicação de diferentes doses de vinhaça na condutividade hidráulica do solo saturado e verificar suas possíveis alterações químicas, destes solos. Para tal, foram utilizadas colunas de PVC (em um esquema de permeâmetro de carga constante para a obtenção dos valores da condutividade hidráulica do solo saturado), preenchidas com três solos (Latossolo Vermelho-Escuro - LVE, Latossolo Roxo - LR e Nitossolo Vermelho Eutrófico - NVE), nas quais foram aplicadas quatro doses de vinhaça (0; 150; 300 e 450 $\mathrm{m}^{3} \mathrm{ha}^{-1}$ ), distribuídas em um delineamento inteiramente casualizado, em esquema fatorial 3x4, com três repetições. Os resultados evidenciaram que apenas o Latossolo Vermelho-Escuro (LVE) apresentou redução nos valores da condutividade hidráulica do solo saturado e que, diante de aplicações de vinhaça, até $300 \mathrm{~m}^{3} \mathrm{ha}^{-1}$, observou-se incremento nas concentrações dos íons potássio, cálcio e capacidade de troca catiônica (CTC).

PALAVRAS-CHAVE: dispersão da argila; potássio; permeabilidade do solo.

\footnotetext{
${ }^{1}$ Professor do Instituto Federal de Educação, Ciências e Tecnologia do Pernambuco - Campus Vitória de Santo Antão - IFPE/Vitória; Vitória de Santo Antão - CEP:55602-970; cauyeda@yahoo.com.br.

${ }^{2}$ Prof. Associado 2, Depto. Engenharia de Biossistemas, Escola Superior de Agricultura "Luiz de Queiroz", ESALQ/USP, jhmirand@usp.br.

${ }^{3}$ Prof. Associado 2, Departamento de Engenharia de Biossistemas da ESALQ/USP. Piracicaba - SP; snduarte@usp.br.

${ }^{4}$ Prof. Dr., Colegiado de Engenharia Agrícola e Ambiental, Universidade Federal do Vale do São Francisco - Campus Juazeiro,

Juazeiro-BA; prfmede@yahoo.com.br.

${ }^{5}$ Professor Titular, Escola Superior de Agricultura "Luiz de Queiroz" - ESALQ/USP, Departamento de Ciências Exatas, PiracicabaSP; e-mail: ctsdias@usp.br.

Recebido pelo Conselho Editorial em: 19-2-2010
}

Aprovado pelo Conselho Editorial em: 4-2-2013 


\section{INTRODUCTION}

The production of sugarcane for ethanol production has increased in recent years, mainly due to the demand for energy sources that reduce the emission of greenhouse gases. However, the production of sugar and alcohol gives rise to so-called liquid waste that can pollute the environment if they are not treated before being discharged into water courses.

In 2005, the State of São Paulo, in Brazil, was the largest producer of sugarcane, accounting for $60.2 \%$ of national production, with an increase of $6.4 \%$ in production, mainly because of having greater acreage, surpassing 3 million hectares, an increase of $4.5 \%$ over the previous year (IBGE, 2006). It is noteworthy that, according to DANTAS NETO et al. (2006), irrigation of sugarcane has been fairly questioned, both by the uncertainty in the plant response, as for its costs. As the largest producer of sugar and alcohol, thus, it is the largest generator of liquid waste, such as washing water of the cane, water of barometric columns, cooling water, among others.

Agricultural use of organic waste from agricultural sources, urban or industrial, is an interesting alternative to disposal, enabling the recycling of nutrients (NPK) in ecosystems (TASSO JÚNIOR, 2007).

The most striking residue is the vinasse, by its large volume produced and its value as agricultural fertilizer. For each ton of sugarcane crushed, it is generated 1,066 liters of vinasse, 82 liters of ethanol and 90 kilograms of sugar. Thus, on average, each liter of ethanol produced has from 10 to 18 liters of vinasse as a residue (SILVA et al., 2007). The most common practice to use this tailing is the fertigation, due to the presence of nutrients (salts) essential to the plant, such as potassium.

The effect of salts on the soil structure occurs primarily by electrochemical interaction between the cations present in the solution and the clay fraction. The main feature of this effect is the expansion of the clay when wet and its contraction when dry, mainly due to excess of exchangeable sodium.

The fine particles in a dispersed soil block its pore space, significantly reducing infiltration. Besides the consequent decrease of the amount of water available to crops, surface crusts are formed, and problems arise from germination and seedling emergence (BAGARELLO et al., 2005).

Regarding the effects of vinasse application on soil physical properties, particularly with respect to the hydraulic conductivity of saturated soil; there is not a consolidated position that is common to the different research studies already developed.

Given the above, starting from the supposed dispersive effect of potassium on clay particles and its suppressive effects on the soil, in relation to its permeability, this study aimed to investigate the possible effect of vinasse in the values of hydraulic conductivity of saturated soil and to verify whether there is chemical enhancement of these soils, when facing the application of vinasse.

\section{MATERIAL AND METHODS}

\section{Collection of soil material}

During the period from March to May, 2009, samples were collected from two soils - Dark Red Latosol (DRL) with vinasse application for over 30 years; and an Purple Latosol (PL) submitted to the application of vinasse for 15 years - both in Iracema Plant, in Iracemápolis city -

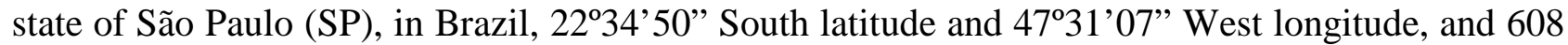
meters of altitude. The third soil samples collected was a Eutrophic Red Nitossol (ERN) ("Luiz de Queiroz" series) with no history of vinasse application, in the experimental area of the Department of Biosystems Engineering (LEB/ESALQ/USP) (Tables 1 and 2). The climatic classification of these regions is CWa (subtropical dry winter, the mean temperature is $22^{\circ} \mathrm{C}$, with absolute maximum temperature of $37.7^{\circ} \mathrm{C}$ and absolute minimum of $3.1^{\circ} \mathrm{C}$. The mean annual rainfall varies between 1,100 and 1,400mm), according to the classification of Köeppen. 
TABLE 1. Physical characteristics from the three soils collected.

\begin{tabular}{|c|c|c|c|c|c|c|}
\hline \multirow{2}{*}{ Soil } & \multicolumn{3}{|c|}{ Granulometry (\%) } & \multirow{2}{*}{$\begin{array}{c}\text { Textural } \\
\text { Class }\end{array}$} & \multicolumn{2}{|c|}{ Density (g. $\mathrm{cm}^{-3}$ ) } \\
\hline & clay & silt & sand & & global & particles \\
\hline$\overline{\mathrm{DRL}}$ & 61.54 & 11.73 & 26.72 & clayey & 1.22 & 2.25 \\
\hline PL & 63.49 & 12.97 & 23.54 & clayey & 1.22 & 2.82 \\
\hline ERN & 41.23 & 13.68 & 45.09 & clayey & 1.45 & 2.43 \\
\hline
\end{tabular}

TABLE 2. Chemical analysis from the three soils collected.

\begin{tabular}{cccccccccc}
\hline \multirow{2}{*}{ Soil } & $\begin{array}{c}\mathrm{pH} \\
\mathrm{CaCl}_{2}\end{array}$ & $\begin{array}{c}\mathrm{O} . \mathrm{M} . \\
\mathrm{g} \mathrm{dm}^{-3}\end{array}$ & $\begin{array}{c}\mathrm{P} \\
\mathrm{mg} \mathrm{dm}^{-3}\end{array}$ & $\mathrm{~K}$ & $\mathrm{Ca}$ & $\mathrm{Mg}$ & $\mathrm{H}+\mathrm{Al}$ & S.B. & $\mathrm{CEC}$ \\
\hline DRL & 4.5 & 33 & 94.5 & 7.7 & 27.5 & 8.7 & 72 & 44 & 116 \\
PL & 5.0 & 33 & 35 & 11.8 & 31 & 11 & 47 & 53.8 & 100.8 \\
ERN & 5.1 & 27 & 6 & 6.9 & 29 & 11 & 28 & 46.9 & 74.9 \\
\hline
\end{tabular}

OM: organic matter, P: phosphorus, K: potassium, Ca: calcium, Mg: magnesium, H+Al: potential acidity, S.B: sum of exchangeable bases, CEC: cation exchange capacity

Deformed samples of soil from Iracema Plant were obtained in a mesh of sampling points, spaced $10 \mathrm{~m}$, in a layer of 0 to $0.20 \mathrm{~m}$ depth. The soil samples of the areas in question (Iracema Plant and the experimental area of LEB/ESALQ/USP) were prepared in the laboratory (air-dried and passed through a $2 \mathrm{~mm}$ sieve).

\section{Statistical design and chemical characteristics of vinasse}

It was used a completely randomized design, in a factorial scheme $3 \times 4$, with the factors: 3 types of soil and 4 vinasse doses $\left(0,150,300\right.$ and $\left.450 \mathrm{~m}^{3} \mathrm{ha}^{-1}\right)$ with three replications. The chemical characteristics of vinasse used are shown in Table 3.

TABLE 3. Analysis of the chemical components of the vinasse used.

\begin{tabular}{|c|c|c|c|c|c|c|c|c|c|c|c|}
\hline \multicolumn{12}{|c|}{ Chemical elements } \\
\hline $\mathrm{N}$ & $\mathrm{P}$ & & $\mathrm{Ca}$ & $\mathrm{Mg}$ & $S$ & $\mathrm{C}$ & $\mathrm{Na}$ & $\begin{array}{c}\mathrm{Cu} \\
\mathrm{mg}\end{array}$ & ${ }_{-1} \mathrm{Fe}$ & $\mathrm{Zn}$ & $\mathrm{Mn}$ \\
\hline 0.35 & 0.06 & 1.91 & 0.97 & 0.20 & 0.47 & 5.20 & 122.00 & 0.40 & 17.00 & 0.70 & 6.00 \\
\hline
\end{tabular}

\section{Assembly of the columns}

Columns of PVC pipe, with dimensions of $25 \mathrm{~cm}$ height and $5 \mathrm{~cm}$ in diameter, were assembled at the Laboratory of Soil Physics of the Department of Biosystems Engineering (ESALQ/USP), to be filled with different soils. To prevent the loss of soil from the bottom of the column without, however, interfering with the process of water draining through the soil column, a synthetic geotextile blanket (Bidim OP-20) was placed, on the bottom of the column, on a screen, and fixed by a threaded "cap". Since this is the assembly of a "constant head permeameter", in order to maintain the constant blade of $1 \mathrm{~cm}$, at the top of the column, it was connected to the column wall (at $1 \mathrm{~cm}$ from the top of the soil) one tube that drained any excess while maintaining constant hydraulic load. The column was part of a structure that was assembled for the values evaluation of hydraulic conductivity, which still had a vessel with a capacity of 60L,60cm clamps, tubes of 16 $\mathrm{mm}$ and microtubes to feed the system with desalinated water (Figure 1). 


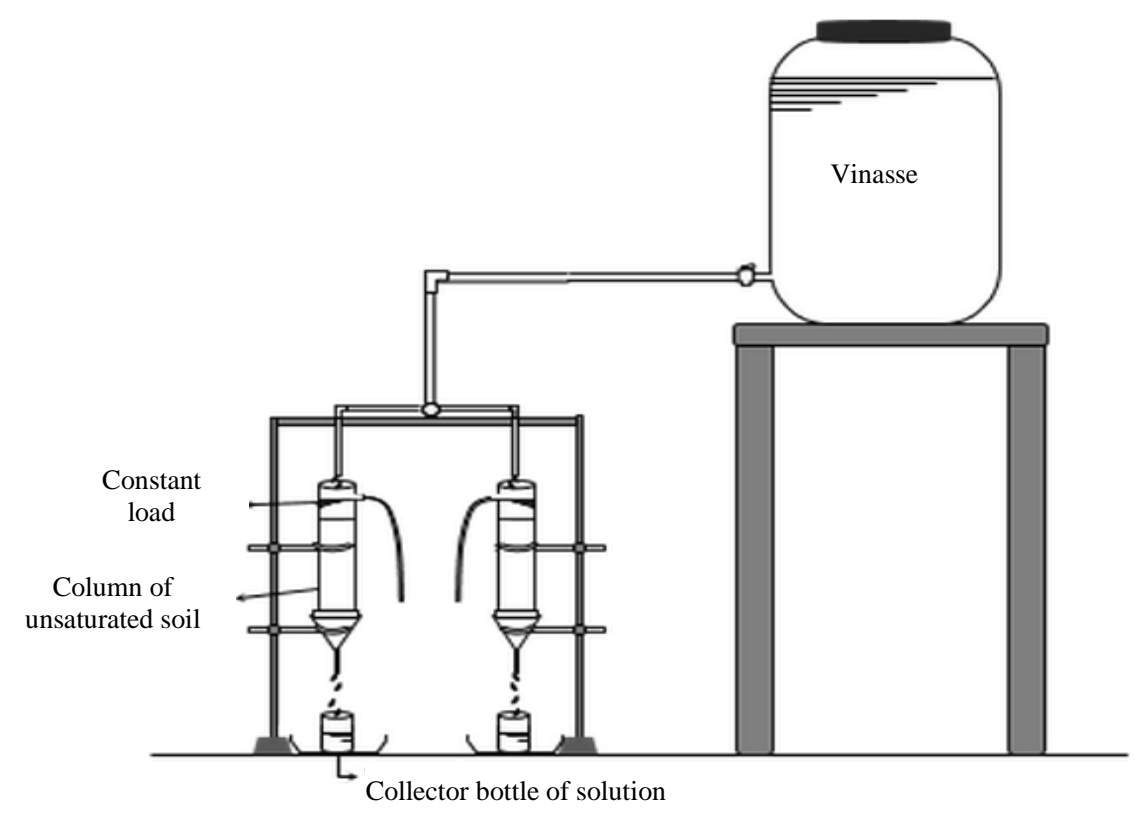

FIGURA 1. Scheme assembled in laboratory (constant head permeameter) to obtain hydraulic conductivity values of saturated soil.

\section{Vinasse application and evaluation of saturated hydraulic conductivity}

After filling the columns with the respective soils, it was applied the vinasse doses for each treatment, and the volume was estimated by the relation between the doses of 150,300 and $450 \mathrm{~m}^{3}$ $\mathrm{ha}^{-1}$ and the cross-sectional area of the columns. We waited for 30 days so that there was an incubation period of vinasse in the soil, and thus the evaluations began.

To start the test, it was necessary to saturate, slowly, the column with deionized water. In this case, the column was placed in a slightly inclined position inside a container and, through a small dripping flow; water was added until a height of approximately $2 / 3$ of the column. Then the assembly was stored for a period of 24 hours to complete the saturation and, after this period, the test was performed. This process was carried out to avoid the problem of formation of air pockets and to facilitate the dissolution of air contained within the sample.

To the beginning of the tests, the columns were fixed to clamps and placed in level with the help of a common bubble level, and then microtubes that dripped deionized water inside them were placed and glued. According to EMBRAPA (1997), the columns remained with a constant hydraulic load for $8 \mathrm{~h}$, and only after this period, proceeded to collect the drained volumes. The volume of water collected was measured at certain time intervals, and when it was identified three consecutive measurements of flow with similar results, we considered that the flow was steady, that is, it had been reached dynamic equilibrium, and therefore there would be no variation of soil moisture in the sample.

At the end of the experiment, the soil columns were dismantled, and the soils of each replication were combined to construct a composite sample. Data obtained were subjected to analysis of variance, using the Statistical Analysis System software, and polynomial regression analysis (FERREIRA, 2000).

\section{RESULTS AND DISCUSSION}

\section{Hydraulic Conductivity}

Regarding the values obtained of the hydraulic conductivity of saturated soil $\left(\mathrm{K}_{0}\right)$, there was a significant effect at $1 \%$ probability between soils evaluated - Dark Red Latosol (DRL), Purple Latosol (PL) and Eutrophic Red Nitossol (ERN) -, and there was no significant effect for vinasse doses and the interaction between the soil and the doses (Table 4). 
TABLE 4. Analysis of variance for hydraulic conductivity of saturated soil.

\begin{tabular}{ccc}
\hline Variation cause & GL & F \\
\hline Soil (S) & 2 & $197.15^{\text {** }}$ \\
Doses of vinasse (D) & 3 & $0.49^{\text {ns }}$ \\
Interaction (S x D) & 6 & $0.32^{\text {ns }}$ \\
\hline
\end{tabular}

$* *=1 \%$ of significance and ns $=$ not significant

Through the Tukey test, DRL and PL soils did not differ from each other, differentiating only the ERL, a fact that was expected, since the ERL presented a difference in its granulometric composition in relation to DRL and PL, with regard to the amount of sand (Table 5). Sandier soils have a higher amount of macrospores than the clayey soils and, consequently, present a higher hydraulic conductivity and infiltration rate (FIORIN, 2008).

TABLE 5. Mean values of hydraulic conductivity of saturated soils $\left(\mathrm{K}_{0}\right)$ for the three different soils.

\begin{tabular}{cc}
\hline Soil & $\mathrm{K}_{0}\left(\mathrm{~cm} \mathrm{~h}^{-1}\right)$ \\
\hline DRL & $1.915 \mathrm{~A}$ \\
PL & $3.168 \mathrm{~A}$ \\
ERL & $22.23 \mathrm{~B}$ \\
\hline
\end{tabular}

\footnotetext{
${ }^{1}$ Means followed by the same letters, in the column, do not differ at $5 \%$ by Tukey test
}

Also note that the PL soil showed a higher hydraulic conductivity value than the DRL, although not significant despite virtually having the same amounts of clay, silt and sand. The PL soil presented a $\mathrm{K}_{0}$ approximately $65 \%$ greater than the DRL. This may be related to the filling of the soil column, which highlights the importance of this step in the study, in order to ensure that the field conditions are adequately represented.

In terms of DRL soil, it was noticed that as they increased the dose values of vinasse application, there was a decrease in the values of the hydraulic conductivity of saturated soil $\left(\mathrm{K}_{0}\right)$. Values ranged from $2.3 \mathrm{~cm} \mathrm{~h}^{-1}$ to $1.40 \mathrm{~cm} \mathrm{~h}^{-1}$ (39\% reduction of the maximum value to the minimum). From the dose of $300 \mathrm{~m}^{3} \mathrm{~h}^{-1}$, the value of $\mathrm{K}_{0}$ was below the mean $\left(1.91 \mathrm{~cm} \mathrm{~h}^{-1}\right)$ reaching the value of $1.4 \mathrm{~cm} \mathrm{~h}^{-1}$ (Figure 2). In a way, for this soil, it can be said that the vinasse showed an effect of reducing the easiness in which water moves, which, somehow, comes against the values obtained by LOBATO et al. (1998). These authors evaluated the variation of hydraulic conductivity of saturated soil of a dystrophic purple latosol with vinasse doses ranging from 0 to $1000 \mathrm{~m}^{3} \mathrm{ha}^{-1}$, and observed that the additions of vinasse doses promoted a decrease in the values of hydraulic conductivity of saturated soil.

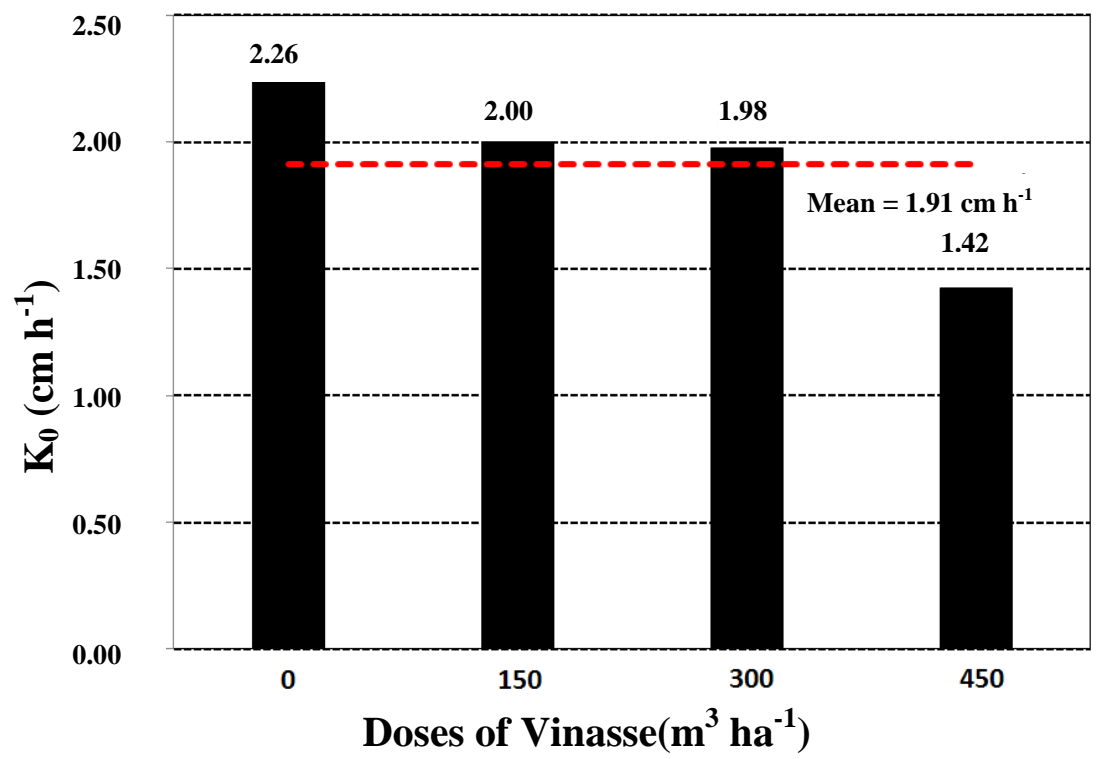

FIGURE 2. Values of hydraulic conductivity of saturated soil $\left(\mathrm{K}_{0}\right)$ in relation to the vinasse doses applied for the Dark Red Latosol (DRL). 
The PL soil showed a reduction of value between the application from $0 \mathrm{~m}^{3} \mathrm{ha}^{-1}$ to $150 \mathrm{~m}^{3} \mathrm{ha}^{-1}$, ranging from $2.9 \mathrm{~cm} \mathrm{~h}^{-1}$ to $2.3 \mathrm{~cm} \mathrm{~h}^{-1}$ (a reduction of approximately $21 \%$ ). However, from the application of $300 \mathrm{~m}^{3} \mathrm{ha}^{-1}$, we noted an increase in the values of hydraulic conductivity of saturated soil, increasing from $3.51 \mathrm{~cm} \mathrm{~h}^{-1}$ to $3.95 \mathrm{~cm} \mathrm{~h}^{-1}$ (an increase around 12.5\%) (Figure 3).

RIBEIRO et al. (1983) worked in laboratory conditions and determined the effect of two samples of different provenances of vinasse on the dispersion of clay fraction of six latosols of different textures and concluded that the vinasse served as dispersant on medium textured soils and as flocculants on clayey soils.

SILVA et al. (2005) evaluated the effects of different management systems with sugarcane in the physical and hydraulic properties of a cohesive Yellow Argisol at Triunfo Plant, in the State of Alagoas. The authors observed an increase in the degree of dispersion of soil clay and an increase of the levels of total clay in the subsurface layers of soils cultivated with sugarcane, in relation to forest soil.

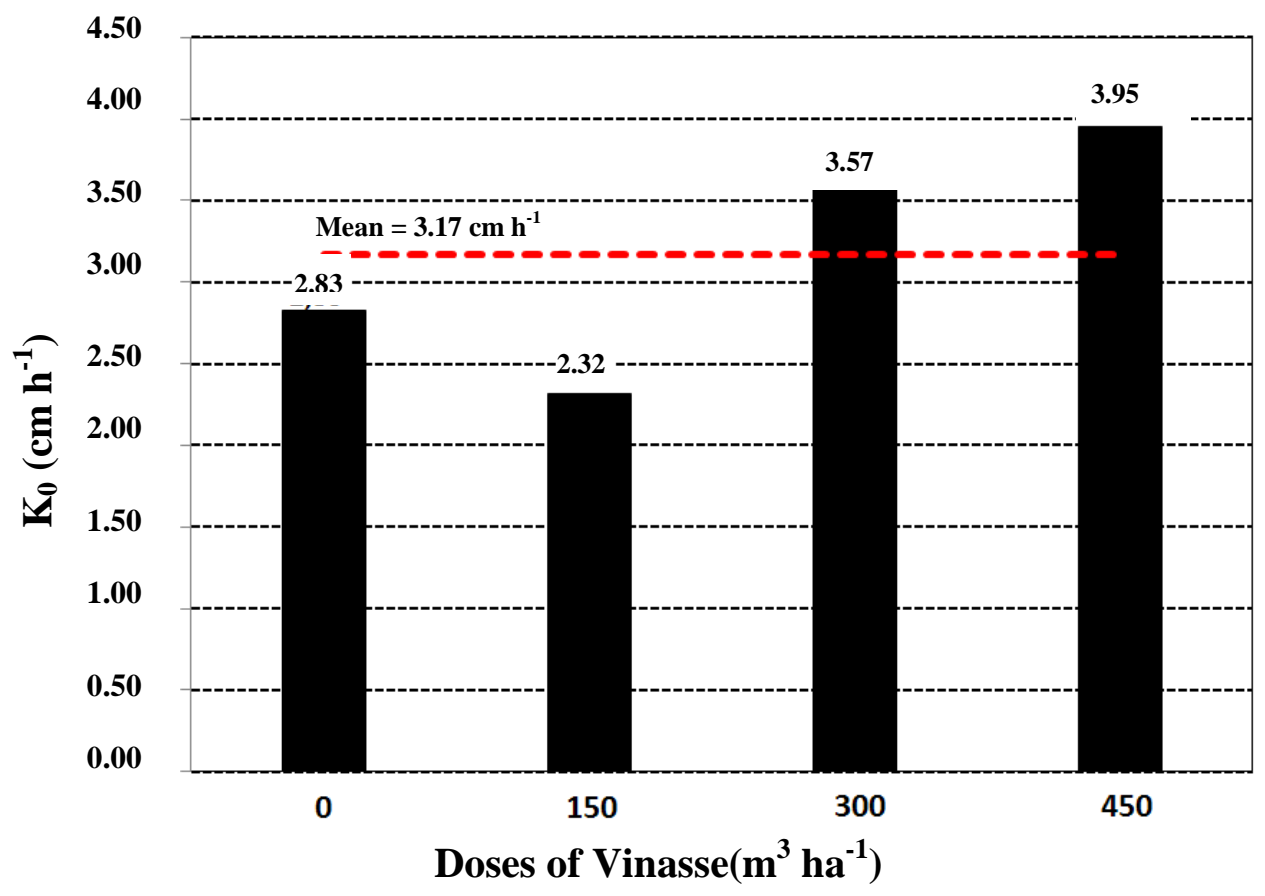

FIGURE 3. Hydraulic conductivity of saturated soil $\left(\mathrm{K}_{0}\right)$ in relation to the vinasse doses for Purple Latosol (PL). Piracicaba city - state of São Paulo (SP), in Brazil, 2009.

In ERL soil, it was observed an increase in the values between the application from $0 \mathrm{~m}^{3} \mathrm{ha}^{-1}$ to $300 \mathrm{~m}^{3} \mathrm{ha}^{-1}$, ranging from $20.95 \mathrm{~cm} \mathrm{~h}^{-1}$ to $24.00 \mathrm{~cm} \mathrm{~h}^{-1}$ (an increase of about $14.6 \%$ ). However, from the application of $300 \mathrm{~m}^{3} \mathrm{ha}^{-1}$, it was noted a decrease in the values of hydraulic conductivity of saturated soil, reducing from $24.00 \mathrm{~cm} \mathrm{~h}^{-1}$ to $22.85 \mathrm{~cm} \mathrm{~h}^{-1}$ (a reduction of around $4.8 \%$ ) (Figure 4). The reason of the decrease can be attributed to higher values of organic matter that were presented between the ranges from $0 \mathrm{~m}^{3} \mathrm{ha}^{-1}$ to $300 \mathrm{~m}^{3} \mathrm{ha}^{-1}$, whose presence led to an improvement of the physical properties, facilitating, in a way, the movement of soil water. 


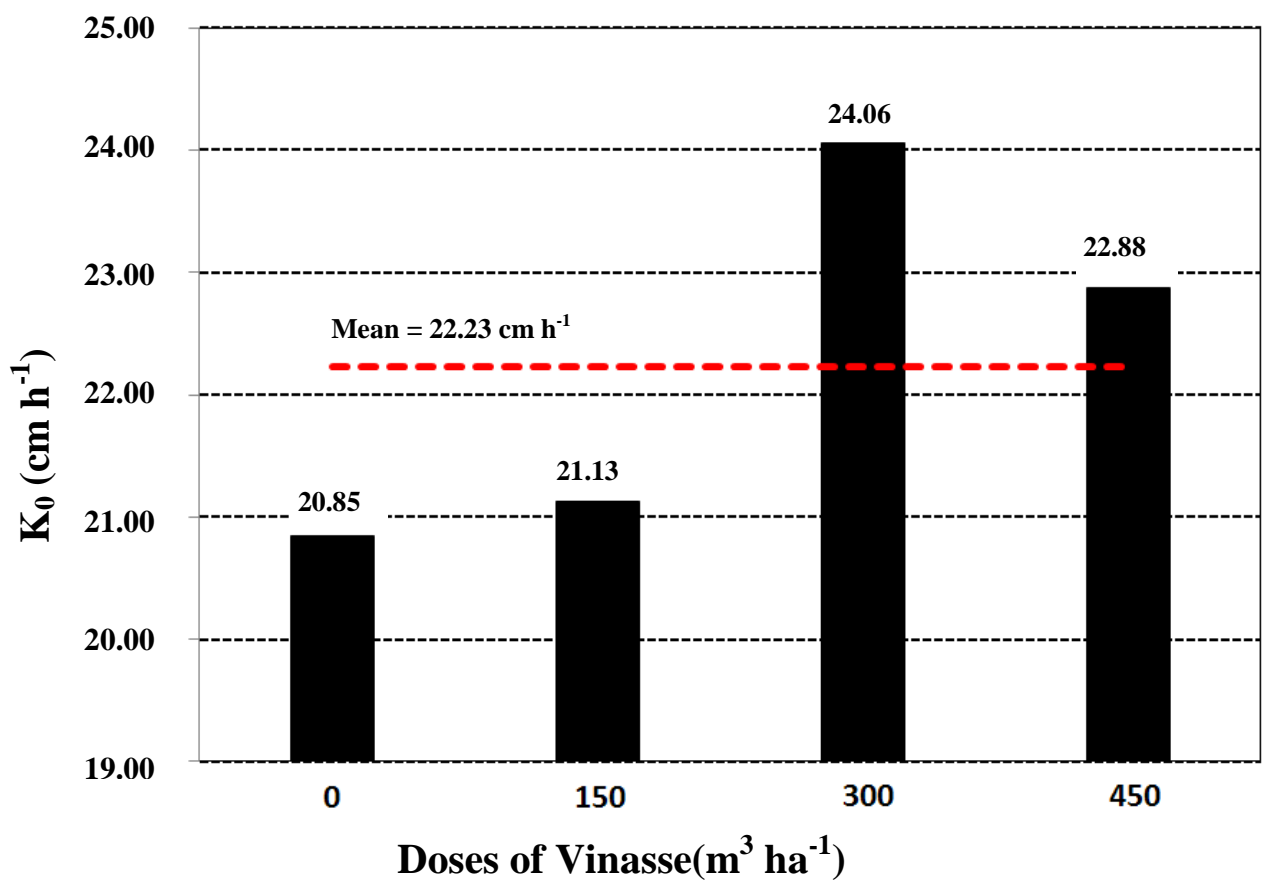

FIGURA 4. Hydraulic conductivity of saturated soil $\left(\mathrm{K}_{0}\right)$ in relation to the vinasse doses for Eutrophic Red Nitossol (ERL). Piracicaba city - state of São Paulo (SP), in Brazil, 2009.

\section{Chemical analysis of soil material}

The high initial $\mathrm{Ca}^{2+}+\mathrm{Mg}^{2+}$ in PL and ERL soils in relation to DRL might have influenced the flocculation effect of clay particles by increasing the $\mathrm{K}_{0}$ of these soils, because the effect of dispersion or flocculation of soil colloids varies with the valence, hydrated radius and concentration. Regarding to flocculation effect on the soil, it has been proposed the following relation: $\mathrm{K}^{+}<\mathrm{Mg}^{2+}<\mathrm{Ca}^{2+}$. Also, the effect on the clay flocculation or dispersion in Latosols will depend on the nature of the clay fraction and the concentration of cations present in the vinasse, and the dose administered (RIBEIRO et al. 1983). This fact was also observed by MELO et al. (2005) while working with the application of cassava waste, liquid waste generated from cassava processing industries, and found the same contrasting effects apparently balanced: the favoring to the dispersion caused by the decrease of the aluminum and the increase of exchangeable sodium and the tendency to flocculation in response to the increased interchangeable calcium, magnesium and potassium.

It was observed the elevation of the contents of potassium $\left(\mathrm{K}^{+}\right)$, calcium $\left(\mathrm{Ca}^{2+}\right)$ and magnesium $\left(\mathrm{Mg}^{2+}\right)$ and of the effective cation exchange capacity of the soil (CEC) (Table 6). Corroborating with AZEVEDO and OLIVEIRA (2005), that when working with wastewater from frigorific chamber and effluent sewage treatment, respectively, found an increase in the values of these ions, even in CEC of the soil. 
TABLE 6. Chemical analysis of composed samples of each treatment after vinasse application.

\begin{tabular}{|c|c|c|c|c|c|c|}
\hline \multirow{2}{*}{ Soil } & \multirow{2}{*}{$\begin{array}{c}\text { Dose } \\
\left(\mathrm{m}^{3} \mathrm{ha}^{-1}\right)\end{array}$} & \multirow{2}{*}{$\begin{array}{c}\text { O.M. } \\
\left(\mathrm{g} \mathrm{dm}^{-3}\right)\end{array}$} & $\mathrm{K}^{+}$ & $\mathrm{Ca}^{2+}$ & $\mathrm{Mg}^{2+}$ & CEC \\
\hline & & & \multicolumn{4}{|c|}{$\mathrm{mmol}_{\mathrm{c}} \mathrm{dm}^{-3}$} \\
\hline \multirow{4}{*}{ DRL } & 0 & 33 & 7.7 & 27.5 & 8.7 & 116.0 \\
\hline & 150 & 29 & 15.6 & 31.0 & 13.0 & 123.6 \\
\hline & 300 & 33 & 19.0 & 33.0 & 14.0 & 124.0 \\
\hline & 450 & 31 & 15.8 & 29.0 & 11.0 & 119.8 \\
\hline \multirow{4}{*}{ PL } & 0 & 33 & 11.8 & 31.0 & 11.0 & 100.8 \\
\hline & 150 & 33 & 18.5 & 48.0 & 16.0 & 140.5 \\
\hline & 300 & 33 & 21.6 & 45.0 & 14.0 & 138.6 \\
\hline & 450 & 33 & 22.1 & 43.0 & 14.0 & 137.1 \\
\hline \multirow{4}{*}{ ERL } & 0 & 27 & 6.9 & 29.0 & 11.0 & 74.9 \\
\hline & 150 & 26 & 13.4 & 41.0 & 14.0 & 102.4 \\
\hline & 300 & 20 & 13.4 & 37.0 & 12.0 & 126.4 \\
\hline & 450 & 24 & 16.1 & 31.0 & 12.0 & 93.1 \\
\hline
\end{tabular}

For CANELLAS et al. (2003), the addition of organic matter in sugarcane fields for a long term, by preserving the straw at harvest or at the vinasse addition, changed the soil chemical properties and provided an improvement in soil fertility.

In terms of the amount of potassium, PL soil showed the highest and rising values, as the vinasse doses were added, from $11.8 \mathrm{mmol}_{\mathrm{C}} \mathrm{dm}^{-3}$, from the initial condition, to $22.1 \mathrm{mmol}_{\mathrm{C}} \mathrm{dm}^{-3}$ for the dose of vinasse $\left(450 \mathrm{~m}^{3} \mathrm{ha}^{-1}\right)$, and presented a mean value of potassium in the soil of $18.5 \mathrm{mmol}_{\mathrm{C}}$ $\mathrm{dm}^{-3}$. Subsequently, it was observed the DRL soil, going from $7.7 \mathrm{mmol}_{\mathrm{C}} \mathrm{dm}^{-3}$ (initial condition) to $19 \mathrm{mmol}_{\mathrm{C}} \mathrm{dm}^{-3}$, until the application of $300 \mathrm{~m}^{3} \mathrm{ha}^{-1}$, after that, it declined reaching a final value of $15.8 \mathrm{mmol}_{\mathrm{c}} \mathrm{dm}^{-3}$ for the application of $400 \mathrm{~m}^{3} \mathrm{ha}^{-1}$, with a mean value of $14.53 \mathrm{mmol}_{\mathrm{c}} \mathrm{dm}^{-3}$. The lowest potassium values were presented by the ERL soil, although they showed a trend of increasing values, but in lower concentrations, ranging from $6.9 \mathrm{mmol}_{\mathrm{C}} \mathrm{dm}^{-3}$ to $16.1 \mathrm{mmol}_{\mathrm{C}} \mathrm{dm}^{-3}$, and had a mean value of $12.45 \mathrm{mmol}_{\mathrm{c}} \mathrm{dm}^{-3}$ (Figure 5A).

In terms of calcium, the PL soil, from the initial condition, presented additions until the application of a dose of $150 \mathrm{~m}^{3} \mathrm{ha}^{-1}$, ranging from $31 \mathrm{mmol}_{\mathrm{C}} \mathrm{dm}^{-3}$ to $48 \mathrm{mmol}_{\mathrm{C}} \mathrm{dm}^{-3}$, after that it had a slight decline concluding with $43 \mathrm{mmol}_{\mathrm{C}} \mathrm{dm}^{-3}$, on the vinasse dose of $450 \mathrm{~m}^{3} \mathrm{ha}^{-1}$. The mean values for this soil were at $41.75 \mathrm{mmol}_{\mathrm{C}} \mathrm{dm}^{-3}$. The ERL soil was soon following, presenting an increase from $29 \mathrm{mmol}_{\mathrm{C}} \mathrm{dm}^{-3}$ to $41 \mathrm{mmol}_{\mathrm{C}} \mathrm{dm}^{-3}$ for the dose of $150 \mathrm{~m}^{3} \mathrm{ha}^{-1}$, but then presented a decrease of values, ending with $31 \mathrm{mmol}_{\mathrm{c}} \mathrm{dm}^{-3}$ with a vinasse dose of $450 \mathrm{~m}^{3} \mathrm{ha}^{-1}$. The calcium mean for the ERL soil remained in $34.5 \mathrm{mmol}_{\mathrm{C}} \mathrm{dm}^{-3}$. The DRL soil, even with the lowest values of calcium concentration, showed an increasing dose until the application of the vinasse dose of $300 \mathrm{~m}^{3} \mathrm{ha}^{-1}$. Only from that it presented a decrease, going to $29 \mathrm{mmol}_{\mathrm{c}} \mathrm{dm}^{-3}$. The mean values in this soil were $30.13 \mathrm{mmol}_{\mathrm{C}} \mathrm{dm}^{-3}$ (Figure 5B).

Magnesium was the ion which showed the lowest concentrations in relation to the others, and showed a similar behavior for all the soils. Just as potassium, PL had the highest values, ranging from $11 \mathrm{mmol}_{\mathrm{C}} \mathrm{dm}^{-3}$ (initial condition) to $16 \mathrm{mmol}_{\mathrm{c}} \mathrm{dm}^{-3}\left(100 \mathrm{~m}^{3} \mathrm{ha}^{-1}\right)$, and then showing a slight reduction to $14 \mathrm{mmol}_{\mathrm{C}} \mathrm{dm}^{-3}$. In terms of mean values, it was around $13.75 \mathrm{mmol}_{\mathrm{C}} \mathrm{dm}^{-3}$, and it was the soil that showed higher mean values. The other two soils had mean values of magnesium very similar. For all soils, the behavior of magnesium was very similar, with an increase of the initial condition for the $100 \mathrm{~m}^{3} \mathrm{ha}^{-1}$, and then slight decreases as increased the vinasse dose values (Figure 5C).

In terms of CEC, the PL soil repeated the behavior, showing the best CEC values, ranging from an initial condition of $100.8 \mathrm{mmol}_{\mathrm{C}} \mathrm{dm}^{-3}$ to $140.5 \mathrm{mmol}_{\mathrm{c}} \mathrm{dm}^{-3}\left(150 \mathrm{~m}^{3} \mathrm{ha}^{-1}\right)$, and then showed a 
slight decrease for the higher doses of vinasse, although the PL was in an intermediate situation of the initial condition of CEC, and the DRL soil presented higher initial value of CEC. In contrast, the DRL soil had very little variation over the applications of vinasse, presenting the mean values of $120.85 \mathrm{mmol}_{\mathrm{C}} \mathrm{dm}^{-3}$. The ERL soil presented an increase of CEC until the dose of $300 \mathrm{~m}^{3} \mathrm{ha}^{-1}$, ranging from $74.9 \mathrm{mmol}_{\mathrm{C}} \mathrm{dm}^{-3}$ (initial condition) to $126.4 \mathrm{mmol}_{\mathrm{C}} \mathrm{dm}^{-3}\left(300 \mathrm{~m}^{3} \mathrm{ha}^{-1}\right)$, then decreased and ended at the vinasse dose of $450 \mathrm{~m}^{3} \mathrm{ha}^{-1}$ in $93.1 \mathrm{mmol}_{\mathrm{c}} \mathrm{dm}^{-3}$. It was the soil that showed the lowest mean values of CEC, ranging around $99.2 \mathrm{mmol}_{\mathrm{C}} \mathrm{dm}^{-3}$ (Figure 5D).
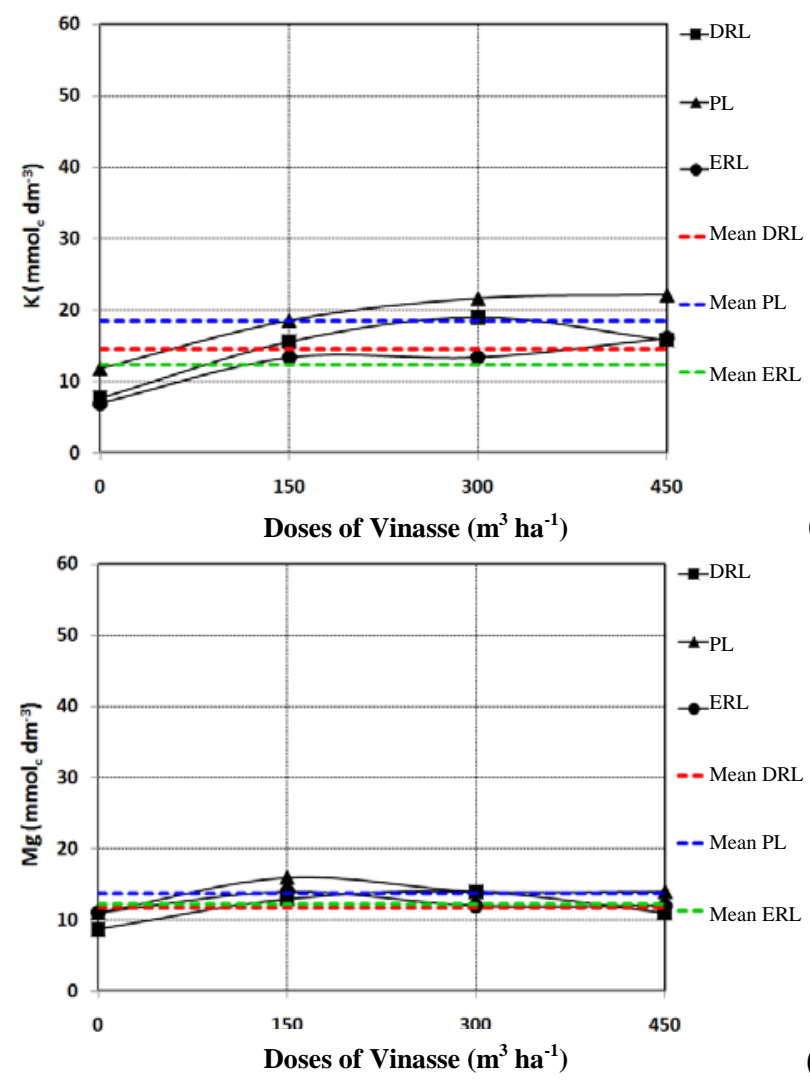

(A)
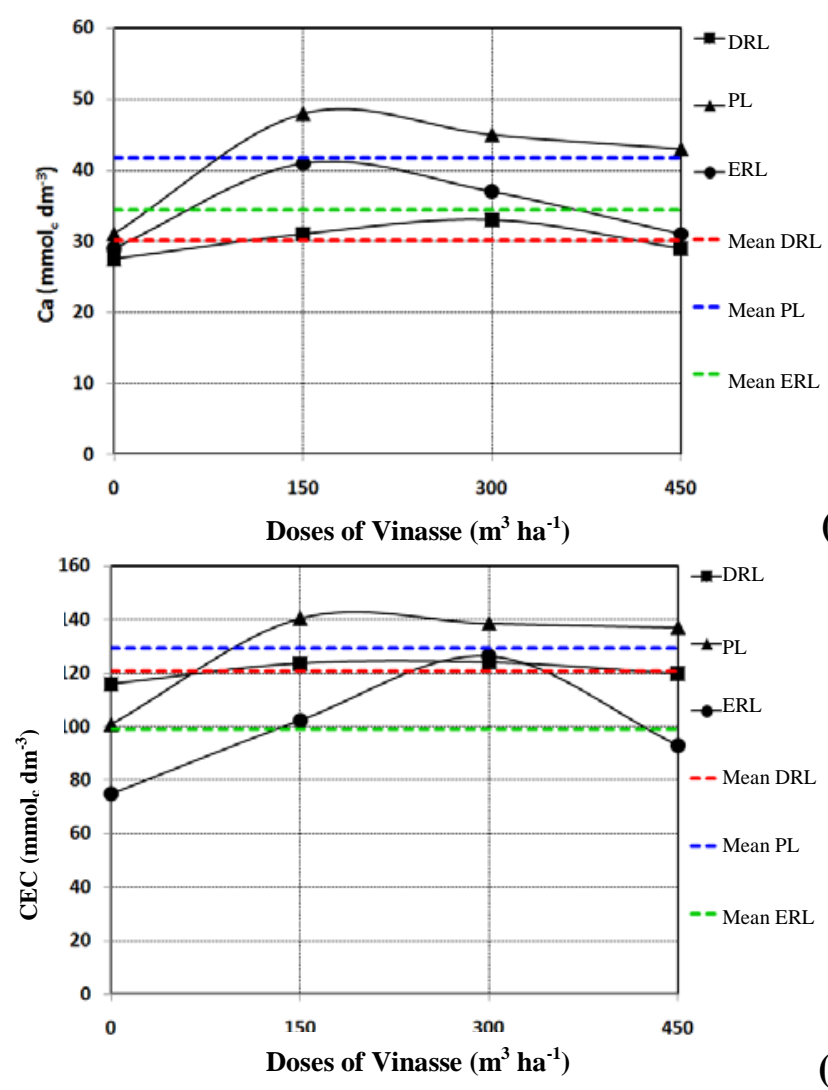

(B)

(D)

FIGURE 5. Absolute and mean concentrations values of ions of potassium, calcium, magnesium and of cation exchange capacity (CEC), for the three soil, under vinasse doses.

\section{CONCLUSIONS}

According to the results obtained, it may be concluded that, in the present study, the different doses of vinasse applied in Dark Red Latosol (DRL), Purple Latosol (PL) and Eutrophic Red Nitossol (ERL) does not significantly change the values of hydraulic conductivity of saturated soil. In terms of chemical improvement, it may be said that for potassium and calcium ions and the cation exchange capacity (CEC), increments were observed until the application of vinasse of $300 \mathrm{~m}^{3} \mathrm{ha}^{-1}$.

\section{ACKNOWLEDGEMENT}

To Iracema Plant and Costa Pinto Plant for access to areas of soil collecting and the vinasse ceded for the experiment. To the National Institute of Science and Technology in Irrigation Engineering for financial support of this study and to the Coordination of Improvement of Higher Education Personnel for the scholarship granted. 


\section{REFERENCES}

AZEVEDO, L.P. de, OLIVEIRA, E.L. de. Efeitos da aplicação de efluente de tratamento de esgoto na fertilidade do solo e produtividade de pepino sob irrigação subsuperficial. Engenharia Agrícola, Jaboticabal, v.25, n.1, p. 253-263, 2005.

BAGARELLO, V.; IOVINO, M.; PALAZZOLO, E.; PANNO, M.; REYNOLDS, W.D. Field and laboratory approaches for determination sodicity effects on satured soil hydraulic conductivity. Geoderma, v. 130, p. 1-13, 2005.

CANELLAS, L.P.; VELLOSO, A.C.X.; MARCIANO, C.R.; RAMALHO, J.F.G.P.; RUMJANEK, V.M.; REZENDE, C.E.; SANTOS, G.A.. Propriedades químicas de um Cambissolo cultivado com cana-de-açúcar, com preservação do palhiço e adição de vinhaça por longo tempo. Revista Brasileira de Ciências do Solo, Viçosa-MG, v.27, n.5, p. 935-944, 2003.

DANTAS NETO, J.; FIGUEREDO, J.L. da C.; FARIAS, C.H. de A.; AZEVEDO, H.M. de.; AZEVEDO, C.A.V. de. Resposta da cana de açúcar, primeira soca, a níveis de irrigação e adubação de cobertura. Revista Brasileira de Engenharia Agrícola e Ambiental, Campina Grande, v.10, p.283-288, 2006.

IBGE - Instituto Brasileiro de Geografia E Estatística. Produção agrícola municipal. Rio de Janeiro, 2006. v. 32, 101p.

EMBRAPA. Manual de métodos de análise de solo. Rio de Janeiro: EMBRAPA Solos, 1997. 212p.

FERREIRA, P.V. Estatística experimental aplicada à agronomia. 2. ed. Maceió:

UFAL/EDUFAL/FUNDEPES, 2000. 437p.

FIORIN, T.T. Estimativa da infiltração de água no solo a partir de pedofunções. 2008. 97f. Tese (Doutorado na área de Ciências do Solo) - Centro de Ciências Rural, Universidade de Federal de Santa Maria, Santa Maria, 2008.

LOBATO, E.J.V, LIBARDI, P.L., CAMARGO, O.A. Condutividade hidráulica de amostras remoldadas de um Latossolo Roxo Distrófico tratado com água/vinhaça. Revista Brasileira de Ciências do Solo. Viçosa-MG, v.22, p 181-188, 1998

MELO, R.F de; FERREIRA, P.A.; RUIZ, H.A.; MATOS, A.T. de; OLIVEIRA, L.B. de. Alterações físicas e químicas em três solos tratados com água residuária de mandioca. Irriga, Botucatu, v. 10, n. 4, p. 383-392, 2005.

RIBEIRO, A.C.; NOVAIS, R.F; BAHIA FILHO, A.F.C. Efeito da vinhaça sobre a dispersão de argila de amostras de latossolos. Revista Ceres, Viçosa-MG, v. 30, n. 167, p. 12-18, 1983.

SILVA, A.J.N. da; CABEDA, M.S.V., LIMA, J.F.W.F. Efeito de sistemas de uso e manejo nas propriedades físico-hídricas de um argissolo amarelo de tabuleiro costeiro. Revista Brasileira de Ciências do Solo, Viçosa-MG, v.29, n.6, pp. 833-842, 2005.

SILVA, M.A.S. da; GRIEBELER, N.P.; BORGES, L.C. Uso de vinhaça e impactos nas Propriedades do solo e lençol freático. Revista Brasileira de Engenharia Agrícola e Ambiental, Campina Grande, v.11, n.1, p.108-114, 2007.

TASSO JÚNIOR, L.C.; MARQUES, M.O.; FRANCO, A.; NOGUEIRA, G. de A.; NOBILE, F.O. de.; CAMILOTTI, F.; SILVA, A.R. da. Produtividade e qualidade de cana-de-açúcar cultivada em solo tratado com lodo de esgoto, vinhaça e adubos minerais. Engenharia Agrícola, Jaboticabal, v.27, p.276-283, 2007. 